\title{
The Role of Zakat on Sustainable Economic Development by Rumah Zakat
}

\author{
Selamat Muliadi \\ STEI Hamzar Lombok Timur \\ Paper to be presented at the $4^{\text {th }}$ International Conference of Zakat (ICONZ) \\ 7-8 October 2020, Surabaya, Indonesia
}

\begin{abstract}
This study aimed to explain conceptual the role of Zakat on sustainable economic development by Rumah Zakat. Rumah Zakat is a philanthropic institution that manage zakat and other social funds through community empowerment programs. In running the program, including economic empowerment and socio health services are designed for these recipients. Rumah Zakat connection with the establisment of SDGs (Sustainable Development Goals) which is to help impoverished recipients economically and socially. The primary goal of Zakat on sustainable economic development, not only limited to economic variables, but based on Islamic principles has comprehensive characteristics. The characteristics includes moral, material, spiritual and social aspects. In other words, sustainable economic development is closely related to improving people living standar. The purpose of this study was to identity the role of Zakat on sustainable economic development, which was applied by Rumah Zakat. This study used the descriptive method and qualitative analysis. The data source was secondary data collected from documents and texts related to the research topic, be it books, articles, newspapers, journals or others. The results showed that the role of zakat on sustainable economic development by rumah zakat has been quite good and in accordance with the principle of Islamic economics. The contribution of the program productive implementation has been aligned with four goals in the sustainable development i.e. Senyum Juara, Senyum Lestari, Senyum Mandiri and Senyum Sehat. Performance of Rumah Zakat in the sustainable economic empowerment community taking into account dimensions such as input, process, output and outcome.
\end{abstract}

Keywords: Islamic Principles, Performance, Rumah Zakat, Social Welfare, Sustainable Economic Development

\section{INTRODUCTION}

One of the performance measurement system in public sector is efficiency. Efficiency deals with both inputs and outputs that measures how productive inputs are turned into outputs. Besides efficiency, there are two other that should measured in public sector. The other two efficiency are economy and effectiveness. Economy represents the relationship between resources expended or budgeted for an activity and what is received for them. Effectiveness focuses mainly on the outputs that refer to goods and services produced as direct result of management activities. The additional measure of performance is outcomes that refer to the consequences of the output produced. (Lailatussufiani et al., 2016)

Sustainable economic development based on Islamic principles not only limited to economic variables, but have comprehensive characteristics include social, moral, material and spiritual. In other words, sustainable economic development is closely related to improving people's living standards. Economic development must tackle the problem of poverty, such as adequate food, provide basic necessities of life and even meet the 
society's nutritional standards. A key tool for human development, including sustainable economic development is zakat, infaq and shadaqah (ZIS). ZIS funds are generally provided as an aid to solve social problems (education, health, housing, etc) as well as assistance for solving economic and financial problems (economic empowerment, economic development, small business, etc). (Triyowati et al., 2018)

Zakat had been practiced since Prophet era in Mecca, but there is the difference between Mecca and Medina era. In Mecca, zakat obligation was only the suggestion for giving voluntarily. The alQur'an verses and al-Hadits was only understood as no obligation for paying zakat and no punishment for negligent. Otherwise, in Medina, paying zakat had been fixed for limit of wealth, time for paying, rate of wealth of zakat and beneficiaries of zakat. Muslim in Mecca faced the unfair condition and zakat was paid voluntarily. However, with a spread of Islam in Arab, Muslim made a lot of wealth, zakat was mandatory paid.

The most common and relevant forms of giving in Islam is zakat. Despite holding an important place in the Islamic faith, the roles and function of zakat and other forms of Islamic charitable giving are not well understood by both Muslim and non-Muslim communities. As one of the five pillars of Islam, zakat is spiritual and religious duty for all Muslim who have the means to do so. Through this, Muslims whose wealth reaches a certain threshold known as nisab, are required to give $2,5 \%$ percent of their accumulated wealth from a lunar year. Those whose wealth falls below the nisab are encouraged to give zakat in the form of goods or by offering a service or providing help to someone in need. (Budiman, 2003)

Islam promotes equitable economic distribution and upholds the right of the poor through zakat and other social funds. These efforts, if properly implemented allow the Muslims to come out of poverty and attain the objectives of the shariah (maqasid al-shariah) through promoting self-actualization goals which aim towards sustaining life, raising future progeny, developing human intellect, safeguarding faith and enjoying fruits of individual efforts through ownership. In this regard, zakat administered in effective ways may prove to be a promising solution to the poverty alleviation problem, particularly in the Muslim countries. While in many Muslim countries, zakat collection programs have been rather efficient. However, effective zakat distribution programs along with mechanisms to ensure sustainable benefits to the receivers. (Pramanik, 2002)

Zakat is integral part of the Islamic economics system based on the Islamic teachings and it's aiming at economic well being of Muslim communities, universal brotherhood and equitable distribution of income. It is designed to establish a community in which every individual or group is committed to social justice, equity and freedom. Islamic economics system are designed not only to attain social well being but rather to gain piety and increase Iman in cognizance with the concept of maqasid alshariah. Many studies have discussed the objectives in establishing a sound society and improve social well being among communities. Although, the concept of their views regarding the objectives of zakat varies according each writers are of interest, concluded that if systematic zakat management is ensured, zakat will play significant role in maintaining social well being among the society. (Hilmiyah, 2018)

Zakat in the economic point of view, becomes significant part of the process of creating purchasing power of the poor, with which they can absorb the goods and services produced by the real sector. Zakat can serve as a balance between supply and demand on the micro-economic sector, that the balance of the market and the prices of products and services can be maintained. If prices can be controlled the poor also can 
also maintain it is purchasing power. The effective management of zakat can help to address the problem of poverty through the creation of purchasing power, the utilization of economic potential, the development of entrepreneurial community and so on. (Norazlina et al., 2011)

Islamic philanthropy activities has been already done when the Muslims came to Indonesia from 8-9 $\mathrm{M}$, including the Muslim traders who come to Indonesia. One theory about the influx of Islam in Indonesia through merchants who come from Gujarat, indirectly the traders have done the practice of zakat. (Karim, 2012). Traders who are at once as a $D a{ }^{\prime} i$ to travel to the Northern part of Sumatera and established Villages known as Samudera Pasai. Whereas in the spread of Islam in Java first accepted by the people who are on the North Coast and eventually extends to the Mataram Kingdom located in Central Java.

Rumah Zakat that focuses on the management of zakat, infaq, shadaqah and waqf professionally by focusing on education, health, community development and economic empowerment as the main program. Through public trust building in 2017, Rumah Zakat is mandated to manage zakat, infaq, shadaqah and waqf funds amounting to Rp. 229.911.992.837. This donation collection is increasing compare to 2016 which amounted to $\mathrm{Rp}$. 225.015.543.720 or increase by $2 \%$. Rumah Zakat receives donation for zakat, infaq, shadaqah and waqf. The largest type of donation received in 2017 is zakat with composition of $48.8 \%$ of the total funds obtained, then followed by receipts on unbound infaq/aims funds that accounted for $21.74 \%$ of the total funds and education funds which reached $12.95 \%$ of total revenue.

In running the program, Rumah Zakat strives to align it's movements and steps with the goals that the government sets. In connection with the establisment of Sustainable Development Goals (SDGs) which is also an important agenda that the government input into the national development even the region. Rumah Zakat has also align the motion to support the intended development. The contribution of the 2017 program implementation has been aligned with four goals in the SDGs namely, No Poverty (Entrepeuneur Assistance Program), Good Health and Well Being (RBG Primary Clinic), Quality Education (School and Juara Scholaship) and Clean Water and Sanitation (Independency of Sanitation).

Therefore, in this study conducted a descriptive study of various factors the effectiveness of managing of zakat in Yogyakarta. Both from the zakat (muzakki), aspect of the manager (amil) as well as from the aspects of the recipient (mustahiq). Results of this study will be very useful as an evaluation and valuable information in order to improve the effectiveness managing of zakat in the future, particularly in the Yogyakarta. The present paper proposes a performance measurement of zakat in the economic empowerment community at Rumah Zakat taking into account dimensions such as input, process, output and outcome.

\section{LITERATURE REVIEW}

Etymologically, the root (masdar) of word zakat is "zaka" means favor, grow-up, clean and good. According lisan al-Arab, the basic meaning of " $z a k a$ " is to increase and to grow. The norms of pre-Islamic Meccan society urged rich people to use portion of their wealth on good causes in order to purify their wealth. Islam continued this tradition and made a religious obligation in the formative years of Islam, zakat signified an act which purified the soul. The moral element was conspicuous whereas the element of legal compulsion and official pressure to give was missing. For Muslims, zakat became closely linked with prayer and is held to purify both the givers and the wealth which 
they give. Before zakat is owed minimum amount of each type of wealth must be owned, called nisab.(Hassan, 2007)

Philanthropy in this paper refers to the act of donating to help people and improve the quality of human lives regardless of any personal return. Rumah Zakat is a philanthropic institution refer to charitable and humanitarian institutions that collect and manage donation to help people. Islamic philanthropy covers all aspect of human needs such as education, food, housing and public servis. The practice of Rumah Zakat in Indonesia clearly show that religious alms giving, such as zakat, infaq, shadaqah and other voluntary donations has contributed significantly to social justice and to the people's welfare. It's simple to generalize Islam as being opposed to human rights by limiting it merely to such things as the equality of men and women by ignoring, instead, Islamic philanthropy as part of human rights considerations. (Kuran, 2001)

The effectiveness generally refers to the rate of output, compared to the input processed by a system. In economic context, the effectiveness describes the ability of a system in generating the maximum desired outputs from the constrained inputs using the available technology. Therefore, the effectiveness improves when output increases while inputs remain the same or reduced. An economic system is effective if it can provide more goods and services, without having to seek out more than the available resources. The effectiveness measurement model were first introduced by Farrell, consisting two components, namely Technical Effectiveness and Allocative Effectiveness. Technical Effectiveness reflects the organizations ability to obtain maximum output from a given set of inputs and Allocative Effectiveness reflects the organizations ability to use the inputs in optimal proportion based on given prices and production technology. The effectiveness in terms of operations is when people and organizations normally work neither as hard nor as effectively as they could. (Ahmad, Ismail HJ \& Ma'in, 2014)

The effectiveness of helping the poor is depends on the method of distribution and also the purpose of it. This method however need to be strengthened and analyzed from time to time so it will serve the purpose to help the poor to have a better life. The previous research which discussed on the effectiveness of the distribution of zakat only touched on few aspects. The method of the distribution of zakat in Islamic perspective needs to satisfy up to the level where the zakat receivers feel comfort with their lives and also for their family members. The distribution needs to reach the ratio which to secure quality of life continuously. (Raudha et al., 2011)

The performance measurement for Islamic based organizations such as zakat organizations are essential to maintain trust between the society and these institutions as mentioned by who stresses that an ideal zakat organizations should be able to synchronize collection and distribution of zakat at any given time. If Rumah Zakat are unable to distribute effectively the collected zakat, this would bring the feelings of lack of trust worthiness among the Muslim especially the zakat payers. Therefore, Muslim would to distributing zakat directly to recipients without the intermediation by government controlled zakat organizations. (Fikriyah, Khusnul \& Ridlwan, 2018)

Some studies show that religiosity has positive effect on development. Many shcolars have proved the close relationship between religion and economic, income, growth, prosperity and development. In another studies even go further proving that Muslim religiosity and support for shariah law have something to do with higher fertility. In a study of zakat and sustainable economic development by Monzer Kahf, the improvement of the economic and social consequences of zakat if collection and distribution models are re-examined to 
make it more efficiency the aim of zakat, which is cleansing and growth.

Through the history of human social economic development process, there is strong evidence proves the role of Islamic institution in giving positive contribution to increase human well being. Moreover, Rumah Zakat reinforces the equity effect of the Islamic mechanism of functional income distribution and wealth. Therefore, Islamic economics argue of the zakat effect three major economic aggregates, namely aggregate consumption, aggregate investment and aggregate supply. The zakat effect on eradication of poverty in the Muslim is hinger if new forms of wealth and new source of income in the sector of industry, commerce, finance and service. The role of zakat in the Islamic economic system is important from the point of view in the society. It can be transferred to the poor as outright grants and given as qardhassan can be used either for investment and consumption purposes. (Saepudin Jahar, 2018)

In general, there are four dimensions of thr model. The first, dimension input or resources allocated to a program. Input is easiest to obtain and simple to measure, but contribute little in measuring performance. Data input includes the perspective of asnaf, staff and institution. The second, dimension process are identifying those having the right to receive zakat (Ibrahim, D., \& RuziahGhazali, 2014). Process are activities generated by a program within organization one of the components to measure performance. The third, dimension output is refers to activities completed by organization. Output refers to the recipients of zakat, activities completed and distribution. The last, outcomes are consequences of the process and outputs. It should the status of recipient due to their involvement in the programs. (Indra, 2018).

\section{RESEARCH METHODOLOGY}

This study used the descriptive method and qualitative analysis was applied for solving the research questions were collected by semi-structured interviews. The data source was secondary data collected from documents and texts related to the research topic be it books, articles, newspapers, journals or others. Data analysis method use author in this research is qualitative method of model Matthew Miles and Michael Huberman.

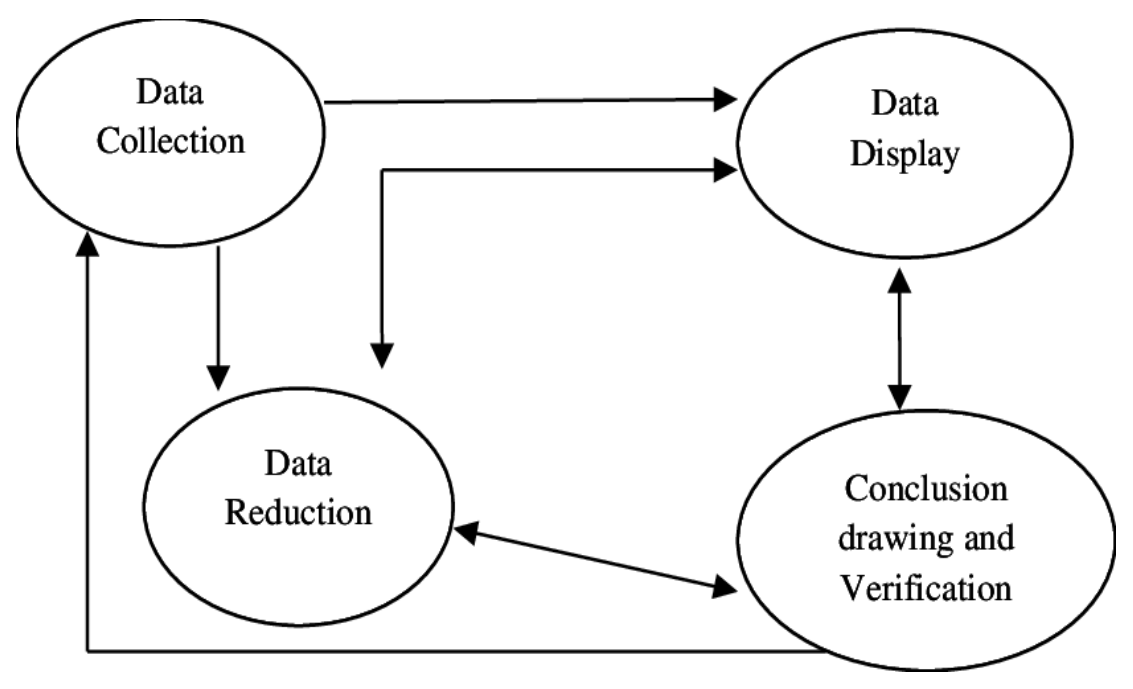

Figure 1. Components of Data Analysis

Source: Miles and Huberman, 1984 
With qualitative approach can preserve the chronological flow assess local causality derive fruitful explanations researchers go beyond initial preconceptions and frameworks.

1. Data reduction: The process of selecting, focusing, simplifying, abstracting and transforming raw data appear in written up field notes. Data reduction occurs continuously throughout the life of any qualitatively oriented project and this part of analysis.

2. Data display: The second major flow of analysis activity is data display. Data display is anorganized assembly of information that permit conclusion drawing and action taking. The most frequent form of display for qualitative data has been narrative text.

3. Conclusion verification: The third stream of analysis activity is conclusion and verification. The beginning of data collection, qualitative analyst is beginning to decide what things mean, regularities, patterns, explanations, causal flows and propositions. The final conclusions may not appear until data collection is over. Conclusion drawing is only half procedure, conclusion are also verified as the analyst proceeds, the meanings emerging from data have tested for their plausibility, their sturdiness and their confirmability (validity).

\section{RESULT AND DISCUSSIONS}

\section{Rumah Zakat Programs}

Desa Berdaya (Integrated Community Development) is an empowernment program carried out in rural areas through integrated approaches such as capacity building, economic, educational, environmental, health and disaster preparation pragram, aimed at growing and developing local institutions empowered to solve their own problems and encouraged to collaborate with other parties, especially the village government. An empowered village is a territory based empowerment design and it defined as community empowerment process carried out by Rumah Zakat facilitator in that village at certain time aimed at helping accelerate repairs to problems that exists in the region. The objective of the program is to create measurable improvements based on the community problems that take place in a region.

There are four sustainable programs that implement in empowered villages, namely in the areas of education, health, economy empowerment and environment initiative. Rumah Zakat also strives to be active in overcoming the social problems of humanity in Indonesia and the world.

\section{Senyum Juara (Educational Programs)}

Education plays a very important role in the progress of a nation because education can change lives and break the cycle of poverty. Rumah Zakat is committed to make improvements quality education that includes categories of beneficiaries students, infrastructure and quality of the students in accordance with the objectives of Sustainable Development Goals ensuring that all Indonesia children complete free uniform and quality primary and secondary education that leads to the impact of lessons learned relevant and effective. As for some programs that run in 2018 are as follows:

a. Juara Scholarship, scholarship program accompanied withperiodic mentoring activities for elementary, junior high school, senior high school and college students from underprivileged families.

b. Sekolah Juara Scholarship, scholarship program fot students 
of Sekolah Juara of Rumah Zakat.

c. Sekolah Juara, construction program free form children underprivileged families.

d. Learning Support, scholarship program is accompanied periodic coaching activities for elementary, junior high school, senior high school and college students from poor families.

e. Best Teacher, program for providing assistance to rural teachers in the form of increased competence, assistance of facilities and infrastructure of teachers in conducting teaching activities and economic assistance.

f. Mobile Libraries, procurement program of media learning in the form of mobile library cars.

g. Healthy Food Aid, healthy supplementary food program for students of Sekolah Juara assisted by Rumah Zakat.

Senyum Juara has several service units in the forms of Sekolah Juara and Mobile Libraries distributed in several regions in Indonesia. Below are the descriptions.

- In 2018, Rumah Zakat already fostered 2.160 Sekolah Juara Students.

- In 2018, Rumah Zakat already awarded Juara Scholarships to 8.325 children.

\section{Senyum Sehat (Health Programs)}

In relation to the derivative of the United Nations SDGs (Sustainable Development Goals) namely Good Health and Well Being which guarantees health and well being for all stages of life as well as in the $2^{\text {nd }}$ goal of SDGs (Zero Hunger) aimed at ending hunger and all forms of malnutrition by 2030, Rumah Zakat realized it in an integrated Senyum Sehat Program.
Senyum Sehat is program at improving the quality of public health on the individual, communal and nongovernment bases.

The programs are realized in several activities such as Free Ambulance, Free Clinic, Health Assistance, Helath Preparedness, Nutritional Garden, etc. When conducting these programs, Rumah Zakat also actively collaborate with various agencies such as related corporations and institutions. In 2018, the RBG clinic (Rumah Bersalin Gratis) of Rumah Zakat served 88.424 benefit services. Since 2018, Rumah Zakat Free Ambulances served 24.747 benefit services. Some programs are implemented on year 2018 is as follows:

a. Free Clinic, the free maternity clinic operations assistance program that is providing general medical services, maternal and children health services, family planning and maternity services for free.

b. Health Asistance, it is a program of channeling direct aid, which is fund disbursed to beneficiaries in cash to meet health care needs.

c. Free Ambulance, ambulance facility procurement program that provides free patient delivery services to people in need.

d. Health Services, health care program in the form of health counseling, free check up and treatment for underprivileged people.

3. Senyum Mandiri (Economic Empowerment)

In relation to the derivative of the United Nations SDGs (Sustainable Development Goals/No Poverty) aimed reducing poverty in all manifestations in 2030 as well as the $11^{\text {th }}$ Goal (Sustainable Cities and Communities) making cities settlements inclusive, safe 
and sustainable. Senyum Mandiri program is an economic empowerment for small and micro enterprises of the needy in order to be able to reduce levels of poverty. The following program are implemented in the year 2018 are:

a. Small and Micro Enterprise Based is economic empowerment program to fostered business in the forms of aid given in the form of facility to support for business activities.

b. Productive Agriculture is empowerment program productive aimed at to encourage young farmers, by means of production facilities, superior seeds and agricultural machinery.

c. Productive Livestock is a program to help farmers have additional income from livestock, through the help of superior seeds and production facilities.

\section{Senyum Lestari (Environment Initiative)}

Sanitation, waste and clean water are global environment issues that every country including Indonesia. Indonesian people of with access to good water sources have already accounted for $84 \%$, however, they are not evenly distributed. In rural areas, the access is lower than of cities, moreover, the poor also have low access to clean water. Through Senyum Lestari Program, focused on environmental issues. Rumah Zakat is committed to improving the quality of the environment and reducing environment related social problems such as water, sanitation and cleanliness. Rumah Zakat works in hundreds of Desa Berdaya (Empowered Villages) to improve their access to sanitation, clean water and hygiene facilities by conducting several programs in the year 2018 as follows: a. Independency Sanitation Post is community care assistance program for latrines, sanitation and provision of access to clean water.

b. Trash Bank (Bank Sampah) is community empowerment program based on waste management in community residence.

c. Water and Sanitation for All is program of providing access to clean water and public sanitation in Rumah Zakat assisted area.

Since 2018, National Disaster Management Agency (BNPB) recorded that 1.999 disaster occured in Indonesia. They largely impacted on the victims 3.548 people were died and lost, 13.112 people were injured, 339.969 houses were severely damaged, 7.810 houses were moderately, 20.608 houses were slightly damaged 3.06 million people were displaced affected by the disaster, and thousands of public facilities were damaged. Rumah Zakat participated in responding to the disasters in almost all disaster points by making various actions, ranging from evacuation, health services, distribution of food and psychosocial services to variety of post disaster recovery programs.

The Role of Zakat on Sustainable Economic Development

Zakat on sustainable economic development is empowernment program that integrates social aspects (education, economic, environment, health and other humanities) with comprehensive aspects whose main funding comes from zakat, shadaqah, waqf and aims to create prosperous independent society. The indicators of zakat on sustainable economic development in particular can be to increase awareness and care of Mustahik beneficiaries about quality of life with indicators: 
- Increasing the number of people donate zakat, infaq, shadaqah and aims.

- Increasing community activities in social.

- Increasing the congregation worship activities.

- Increasing the number of nongovernmental organizations supporting the community empowerment program.

- Increasing the quality of people's behavior, knowledge and skills.

- Increasing the income of community members (income per capita) and

- Increasing the walfare and independence of the community.

States that the assistance for micro small business aims to encourage the increased income for individual and group beneficiaries. Participation is a basic principle of sustainable economic development in accordance with the way the community wants while respecting local knowledge and talents. Sustainable economic development ultimately depends on the participation of people from the initial planning stage to completion. The principle of sustainable economic development is basic principle of Rumah Zakat that is often hard to achieve. The principle of sustainable include active participation of community in all aspects of the project such as problems, needs, identification, implementation, planning, monitoring dan eveluation.

The role of zakat in Islamic economics system is important from the point of view addressing the question of poverty in the society. Zakat can be integrated into the microfinance programs in variety of ways to benefit the beneficiaries. It can be transferred to the poor people as grants or given as qardhassan and can be used either for consumption also for investment purpose. Zakat can play crucial and extended role in directing, effecting and shaping the Islamic economy. It's has to eradicate poverty, ensure equitable distribution of wealth to the desired level, promote social, act as counter cyclical economic stabilization device and common welfare.(Muhtada, 2014)

The efforts of increasing human welfare of globalization era have become the important agenda for every government in the world, especially the world countries who has the majority of the Islamic community. Many policies have been made in effort to improve of welfare condition for Islamic ummah. This is because Islamic view to welfare is as essential factor very important for every human being. Islam have requires man to maintain balance between his love and abstinence from material things. Islam see human status and role will specifying the responsibilities of man as such of a Muslim and the Muslim ummah, that essentially stands to the fundamental unity and brotherhood of mankind. Zakat can help promote balance between individual and social interest can actualize the maqashid shariah also be referred to as the vision of Islam. Two of the most important constituents of which are socio economic justice and well being of all.

Sustainable development is a concept associated with improvement not longer seen as a primarily process of capital accumulation but rather as a process of organizational change as the development of wealth, infrastructure, comforts, conveniences, technology and resources possessed. The process of sustainable welfare create and providing necessities for public to maintain opportunities and choices of a society. In my opinion, development is not anything abstract. It's real change in the lives of people, it means enabling those people to be better off and build better life for themselves. The main goal is to achieve sustained economic growth and promote sustainable development to eradicate poverty.

The Islamic philanthropy institution of the approach to development are follows: 
Tauhid (Allah unity and sovereibnty), Rububiyyah (divine arrangement for nourishment, directing and sustenance things towards their perfection), Khalifah (man's role as Allah vicegerent on earth) and Tazkiyah (purification plus growth). In the economy context, development is largely technical process involving to improvement of market institutions, price reform and free market entrepreneurial activity. Efficiency and growth are preeminent, also regarded as process whereby the per capita real income increases accompanied by reduction in inequalities of income and satisfaction of the preferences of the masses as whole. Sustained improvement and balanced in the material and non-material well being of man and development as multidimensional process that involves improvement of welfare through advancement, reorientation and reorganization of the entire economic, social system and spiritual uplift in accordance with Islamic teachings.

For the development of social context are the process of organizing human energies and activities at higher levels to achieve greater results. Reduction of poverty and ensuring social justice are important part of the Islamic system. In my opinion, human development lies at the heart of overall development process and the well being of people. Human developmnet must not only grapple with four material dimensions (capabilities, intellectual, technical, organizational) in space and time. Islamic approach has couple of benefits, first, people feel more comfortable adapting to these norms they take them as part of belief and worship. Second, the Islamic social development program build the social capital which help repayment of installments regularly.(Saepudin Jahar, 2018)

\section{Zakat Distribution}

Implementation of zakat does not only focus on the payment of zakat alone, but it is being completed after funds of zakat were distributed to the right recipients. The scholars have defined each of these group or zakat recipients with different definitions. An explanation of each definition recipients are as follows:

1. The Poor (al-Fuqara), an individual Muslim who does not have a job or got a source of income does not reach $50 \%$ of the requirements and does not have enough for daily needs.

2. The Needy (al-Masakin), an individual Muslim who have a job and earn source of income that met half of requirement and does not have enough for daily needs.

3. Zakat Collectors (Amil), an individuals or organizations that are directly involved in the management and administration of the zakat affairs, including the collection, distribution and so on.

4. Ransoming of Slaves (al-Riqab), individuals who were freed from the bondage of slavery and conquest whether physical or mental. Since slavery was abolished nowadays, the definition is expanded includes liberation from ignorance, political, economic and so on.

5. The Debtors (al-Gharimin), individuals who is in debt but needs assistance to meet basic.

6. The Cause of Allah (Fi Sabilillah), strive in the cause of Allah for the betterment of the community. Individual who engage in activities to manage, develop, uphold, defend and dakwah.

7. The Wayfarers (Ibnu Sabil), stranded travellers on a permissible journey. Individuals who travel and financial outages or need help.

8. Those Newly Converted to Islam (Muallaf), an individual who tamed heart to Islam and to accept Islamic orientation. (Mohd khairul firdaus \& Khairuldin, 2013) 
Economics Empowerment Community

The implementation of Rumah Zakat has made the utilization of zakat in the form of empowerment, i.e Senyum Juara (education), Senyum Sehat (health) Senyum Mandiri (economic empowerment) and Senyum Lestari (environment)

Table 1. Receipt of Funds

\begin{tabular}{lccc}
\hline \multirow{1}{*}{ Receipt } & \multicolumn{3}{c}{ Year } \\
\cline { 2 - 4 } & $\mathbf{2 0 1 6}$ & $\mathbf{2 0 1 7}$ & Total \\
\hline $\begin{array}{l}\text { Receipt of Educational } \\
\text { Funds }\end{array}$ & 34.170 .019 .037 & 29.778 .354 .804 & $\mathbf{6 3 . 9 4 8 . 3 7 3 . 8 4 1}$ \\
\hline $\begin{array}{l}\text { Receipt of Health Care } \\
\text { Funds }\end{array}$ & 4.855 .279 .793 & 4.001 .280 .722 & $\mathbf{8 . 8 5 6 . 5 6 0 . 5 1 5}$ \\
\hline $\begin{array}{l}\text { Receipt of Economic } \\
\text { Empowerment Funds }\end{array}$ & 1.575 .333 .738 & 1.690 .146 .290 & $\mathbf{3 . 2 6 5 . 4 8 0 . 0 2 8}$ \\
\hline $\begin{array}{l}\text { Receipt of } \\
\text { Environmental funds }\end{array}$ & 1.399 .360 .862 & 3.492 .824 .986 & $\mathbf{4 . 8 9 2 . 1 8 5 . 8 4 8}$ \\
\hline Anval Report Rum & & & \\
\hline
\end{tabular}

Source: Annual Report Rumah Zakat 2018

\section{Mustahiq Empowerment Strategy}

Theoretocally as well as practices, mustahiq empowerment not enough with just giving money in the form of consumer, but it requires sinergisme, alignment (mentoring and institutional) and strengthening of the important aspects of the self and the community of mustahiq. Zakat which can be collected in the long term should empower mustahiq to the level of recreating independence business. Mustahiq empowerment strategy towards self sustainability effort can be done with the approach of the input, process, output and outcomes. With self reliance groups then the joint venture can further developed so it can be expected that many mustahiq (recipient of the zakat) which wiil become muzakki.

Theoretocally as well as practices, mustahiq empowerment not enough with just giving money in the form of consumer, but it requires sinergisme, alignment (mentoring and institutional) and strengthening of the important aspects of the self and the community of mustahiq. Zakat which can be collected in the long term should empower mustahiq to the level of recreating independence business.
Mustahiq empowerment strategy towards self sustainability effort can be done with the approach of the input, process, output and outcomes. With self reliance groups then the joint venture can further developed so it can be expected that many mustahiq (recipient of the zakat) which wiil become muzakki.

The first empowerment phase starts from mustahiq pledge to cultivate intrinsic motivation, then conducted training to enhance the technical capabilities of the mustahiq, which was strengthened with the impetus to seek to foster and enhance the mustahiq entrepreneurial spirit. Next step is the reinforcement of the group to generate a dynamic group, then carried out the development of a joint venture to strengthen the business group was formed. After that the strengthening of the joint venture will be capable of stimulate of business development group so formed more powerfull business. The overall program of empowerment conducted embody the independence efforts ranging from individual mustahiq to materialize independence group, expected to be a new program implementing the empowerment phase. (Hamzah, 2017) 


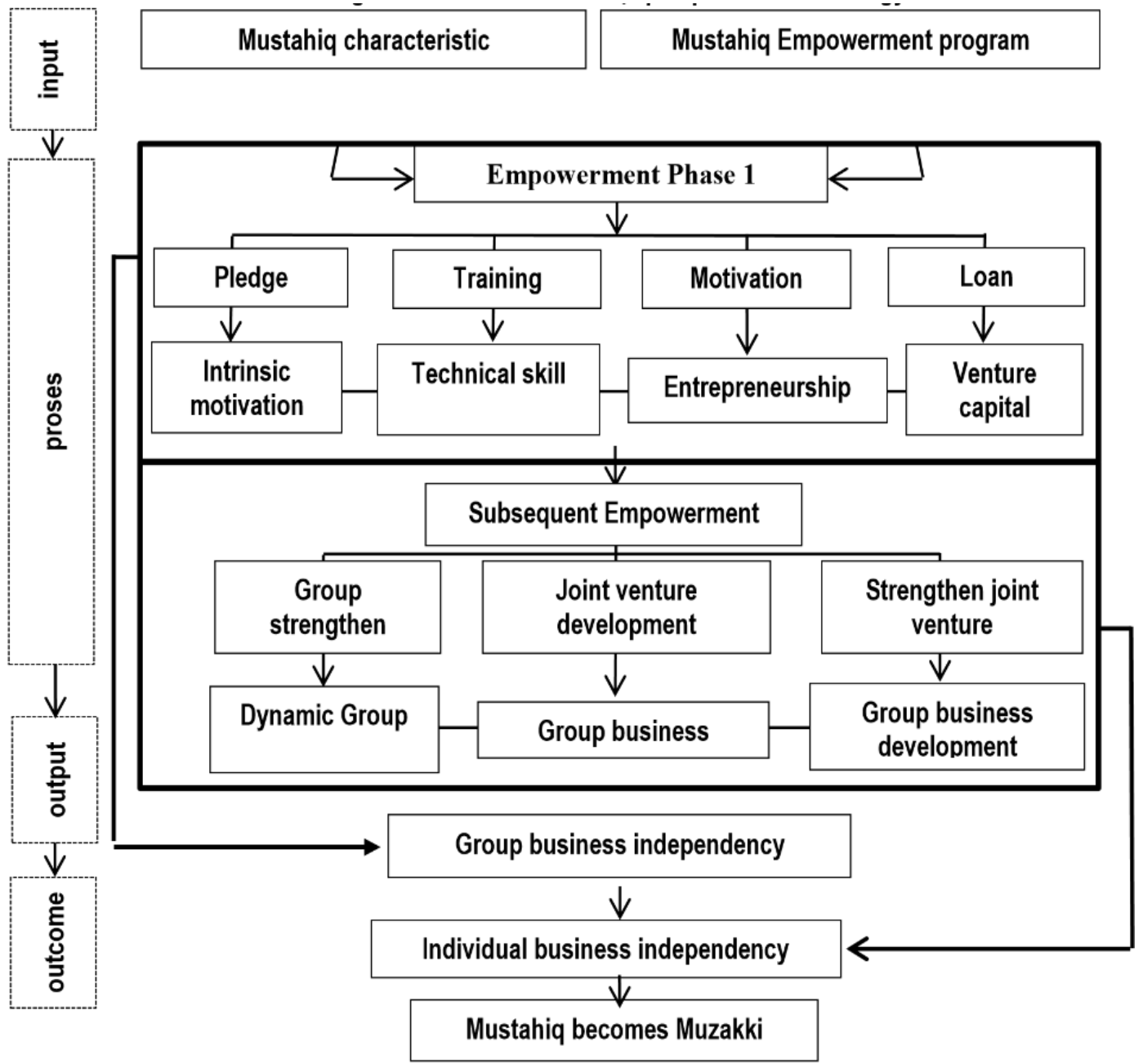

Figure 2. Scheme of Mustahiq Empowerment Strategy

Source: Hamzah, 2017

The Impact of Economic Empowerment Community

Based on interviews with mustahiq, the result showed that assistance from Rumah
Zakat in the form of business capital and infrastructure had a positive impact on the economic empowerment community.

Table 2. The Impact of Economic Empowerment Community

\begin{tabular}{lllc}
\hline \multicolumn{1}{c}{ Name } & Years of Join & \multicolumn{1}{c}{ Income/month } & $\begin{array}{c}\text { Percentage After } \\
\text { Join in Rumah } \\
\text { Zakat }\end{array}$ \\
\hline Suprihatin & April 2016 & $\begin{array}{l}\text { Before }: 400.000-600.000 \\
\text { After }: 600.000-800.000\end{array}$ & $44 \%$ \\
\hline Atik Triyani & January 2015 & $\begin{array}{l}\text { Before }: 400.000-500.000 \\
\text { After }: 600.000-700.000\end{array}$ & $22 \%$ \\
\hline Eko & January 2015 & $\begin{array}{l}\text { Before }: 1.200 .000-1.500 .000 \\
\text { After }: 1.600 .000-2.000 .000\end{array}$ & $30 \%$ \\
\hline Novia Suci & January 2015 & $\begin{array}{l}\text { Before }: 900.000-1.200 .000 \\
\text { After }: 1.300 .000-1.800 .000\end{array}$ & $47 \%$ \\
\hline Rusli & January 2015 & Before : $500.000-600.000$ \\
After $: 1.000 .000-1.500 .000$ & $90 \%$ \\
\hline
\end{tabular}




\begin{tabular}{lccc}
\hline Name & Years of Join & Income/month & $\begin{array}{c}\text { Percentage After } \\
\text { Join in Rumah } \\
\text { Zakat }\end{array}$ \\
\hline Hasan & 2014 & Before $: 1.000 .000-1.500 .000$ & $50 \%$ \\
& & After $: 1.500 .000-2.000 .000$ & \\
\hline Sutrismi & 2013 & Before $: 9.000 .000-1.000 .000$ & $90 \%$ \\
& & After $: 1.800 .000-2.000 .000$ & \\
\hline
\end{tabular}

Source: Interview with Mustahiq

\section{Benficiaries of Service Benefits}

The amount of service benefit in each program depends on the amount of incoming funds contribution to the program. Most service benefit in 2017 is Senyum Lestari Program, it is influenced by program service which is not included into Senyum Sehat, Senyum Juara and Senyum Mandiri, so adds service into the category of Senyum Lestari. Here is the composition of service benefit of Rumah Zakat program over the last 5 years.

Table 3. Service Benefits

\begin{tabular}{rrrrrrr}
\hline \multicolumn{7}{c}{ PROGRAM } \\
\hline Year & $\begin{array}{c}\text { Senyum } \\
\text { Sehat }\end{array}$ & $\begin{array}{c}\text { Senyum } \\
\text { Juara }\end{array}$ & $\begin{array}{c}\text { Senyum } \\
\text { Mandiri }\end{array}$ & $\begin{array}{c}\text { Senyum } \\
\text { Lestari }\end{array}$ & Total & Growth \\
\hline $\mathbf{2 0 0 3}$ & 9.129 & 2.506 & 227 & 674 & 12.536 & - \\
\hline $\mathbf{2 0 0 4}$ & 14.692 & 4.115 & 363 & 702 & 19.872 & $\mathbf{5 9 \%}$ \\
\hline $\mathbf{2 0 0 5}$ & 19.100 & 5.715 & 472 & 913 & 26.200 & $\mathbf{3 2 \%}$ \\
\hline $\mathbf{2 0 0 6}$ & 24.829 & 9.782 & 613 & 1.186 & 36.410 & $\mathbf{3 9 \%}$ \\
\hline $\mathbf{2 0 0 7}$ & 86.759 & 18.712 & 43 & 71 & 105.585 & $\mathbf{1 9 0 \%}$ \\
\hline $\mathbf{2 0 0 8}$ & 149.033 & 25.101 & 41.112 & 42.613 & 257.859 & $\mathbf{1 4 4 \%}$ \\
\hline $\mathbf{2 0 0 9}$ & 197.089 & 28.095 & 58.745 & 15.821 & 299.750 & $\mathbf{1 6 \%}$ \\
\hline $\mathbf{2 0 1 0}$ & 241.172 & 277.004 & 57.698 & 77.755 & 653.629 & $\mathbf{1 1 8 \%}$ \\
\hline $\mathbf{2 0 1 1}$ & 329.381 & 228.859 & 214.409 & 65.931 & 838.580 & $\mathbf{2 8 \%}$ \\
\hline $\mathbf{2 0 1 2}$ & 537.875 & 642.009 & 336.107 & 26.356 & 1.542 .347 & $\mathbf{8 4 \%}$ \\
\hline $\mathbf{2 0 1 3}$ & 862.945 & 747.076 & 350.575 & 515.096 & 2.475 .692 & $\mathbf{6 1 \%}$ \\
\hline $\mathbf{2 0 1 4}$ & 1.112 .193 & 504.456 & 450.868 & 570.680 & 2.638 .197 & $\mathbf{7 \%}$ \\
\hline $\mathbf{2 0 1 5}$ & 1.874 .976 & 804.444 & 569.316 & 1.238 .788 & 4.487 .524 & $\mathbf{7 0 \%}$ \\
\hline $\mathbf{2 0 1 6}$ & 1.438 .558 & 952.940 & 859.829 & 2.581 .980 & 5.833 .307 & $\mathbf{3 0 \%}$ \\
\hline $\mathbf{2 0 1 7}$ & 1.604 .605 & 997.031 & 849.761 & 2.881 .137 & 6.332 .534 & $\mathbf{9 \%}$ \\
\hline Accumulation & $\mathbf{8 . 5 0 2 . 3 3 6}$ & $\mathbf{5 . 2 4 7 . 8 4 5}$ & $\mathbf{3 . 7 9 0 . 1 3 8}$ & $\mathbf{8 . 0 1 9 . 7 0 3}$ & $\mathbf{2 5 . 5 6 0 . 0 2 2}$ & \\
\hline
\end{tabular}

Source: Annual Report Rumah Zakat 2017

\section{CONCLUSION}

Rumah Zakat contibute significantly to serve public needs, it's important to strengthen their roles as part of the four programs. Empowetment programs by Rumah Zakat are classifed into four categories, including Senyum Juara (education), Senyum Sehat (health) Senyum Mandiri (economic empowerment) and Senyum Lestari (environment). For instance, the programs of utilizing zakat for the economic empowerment community effects on the mustahiq.

Based on the above empiricial assessment, can be concluded that zakat distribution for the economic empowerment community in Yogyakarta is possible for reducing inequality and ending 
poverty. This can be an example program for other regions in Indonesia, including in urban communities. From the calculating of four indexes can conclude that the program is effective for reducing the poverty, as well as can increase of the welfare level among the beneficiaries.

\section{REFERENCES}

Ahmad, Ismail HJ \& Ma'in, M. (2014). The Efficiency of Zakat Collection and Distribution: Evidence from Two Stage Analysis. Journal of Economic Cooperation and Development, 35(3), 133-170.

Budiman, B. (2003). The Potential of ZIS Fund as an Instrument In Islamic Economy: Its Theory. Iqtisad : Journal of Islamic Economics, 4(2), 119-143.

Fikriyah, Khusnul \& Ridlwan, Ah. A. (2018). The Evaluation of Mustahiq Empowerment Based Poverty Alleviation Program at Amil-Zakat Organizations. International Journal of Islamic Business and Economics, 2(1), 65-73.

Hamzah. (2017). Empowerment of Mustahiq Zakat Model Towards Business Independency. International Journal of Nusantara Islam, 05(01), 85-96.

Hassan, R. (2007). Giving and Gaining Philantropy and Social Justice in Muslim Societies. Lahore : Journal of Policy Studies, 1(1), 25-34.

Hilmiyah, U. L. (2018). Measuring The National Zakat Index on Zakat Performance in Bogor Regency. Journal of Islamic Monetary Economics and Finance, 3, 179-192.

Ibrahim, D. \& Ruziah Ghazali, (2014). Zakah as an Islamic Micro-Financing Mechanism to Productive Zakah Recipients. Asian Economic and Financial Review, 4(1), 117-125.
Indra, S. (2018). Economic Empowerment Model for the Poor Through Zakat Institution Under Maqashid Syariah Concept in West Kalimantan. Asian Journal of Social Science Studies, 3(1), 54-62.

Kuran, T. (2001). The Provision of Public Goods under Islamic Law : Origins, Impact, and Limitations of the Waqf System. The Journal of Law and Society Association, 35(4), 841-898.

Lailatussufiani, S., Burhan, M. U., \& Multifiah. (2016). The Utilization of Zakat, Infaq and Shadaqah for Community Empowerment (Case Study of BAZNAS West Nusa Tenggara Province ). International Journal of Business and Management Invention, 5(10), 152-160.

Mohdkhairulfirdaus, W., \& Khairuldin, W. (2013). The Philosophy and Elasticity of Zakah Distribution in Islam. International Journal of Education and Research, 1(8), 1-12.

Muhtada, D. (2014). Islamic Philanthropy and the Third Sector: The Portrait of Zakat Organizations in Indonesia. Islamika Indonesiana, 1(1), 106.

Norazlina, A. W., Abdul Rahim, A. R., \& Wahab, N. A. (2011). Efficiency of Zakat Institutions and Its Determinants. 8th International Conference on Islamic Economics and Finance, October, 1-19.

Pramanik, A. H. (2002). Islam and Development Revisited with Evidences from Malaysia. Islamic Economic Studies, 10(1), 39-74.

Saepudin Jahar, A. (2018). Developing Islamic Philanthropy for Human Rights: The Indonesian Experience. International Conference on Law and Justice, 162(ICLJ 2017), 1-4.

Triyowati, H., Masnita, Y., \& Khomsiyah. (2018). Toward Sustainable Development Through Zakat, Infaq, Sadaqah Distributions For the 
Development of Social Welfare and

Micro and Small Enterprises.

Australian Journal of Islamic Studies, 3(2), 39-52.

Selamat Muliadi

Lecturer

STEI Hamzar Lombok Timur selametmuliadi@gmail.com 
